\title{
Pengaruh Ekstrak Kemangi (Ocimum basilicum forma citratum) terhadap Perkembangan Lalat Rumah (Musca domestica) (L.)
}

\author{
DATTU IFFAH H ${ }^{1)}$, DWI JAYANTI GUNANDINI' ${ }^{2)}$, AGUS KARDINAN ${ }^{3)}$ \\ ${ }^{1)}$ Alumnus Program S1, Fakultas Kedokteran Hewan, IPB \\ ${ }^{2)}$ Laboratorium Entomologi Departemen Ilmu Penyakit dan Kesehatan Masyarakat \\ (IPHK) FKH IPB \\ ${ }^{3)}$ Balai Penelitian Tanaman Obat dan Aromatik \\ (diterima September 2007, disetujui Februari 2008)
}

\begin{abstract}
Effect of Kemangi Extract (Ocimum basilicum forma citratum) to House Fly (Musca domestica) (L.). The aim of this study was to know larvacidal effect of basil leave on house fly (Musca domestica). Using atsiri oil which extracted through the steam distillation procedure, this study applied 5 treatments and 4 replications. The treatment were $2.5,5,10$, and $20 \%$ asitri oil dilluted on water compared to control (water only, 0\%), The study showed that $20 \%$ dilluotion has highest larvacidal effect, cause highest mortality rate $(83 \%)$, and inhibited ecdysis shown by lowest ecdysis and enclosy ability sharing only 13 and $37 \%$.
\end{abstract}

KEY WORDS: larvacidal, house fly, Ocimum basilicum forma citratum

\section{PENDAHULUAN}

Serangga merupakan jenis hewan yang paling banyak populasinya di dunia. Kehadiran serangga di alam bisa mendatangkan manfaat dan keuntungan, namun tidak sedikit pula yang mendatangkan masalah dan kerugian. Contoh serangga yang mendatangkan kerugian adalah lalat.

Saat ini cara pengendalian serangga pengganggu tersebut dengan menggunakan insektisida, baik insektisida nabati maupun sintetik (Prijono \& Triwidodo 1993). Sejak tahun 1950 penggunaan insektisida nabati tergeser oleh insektisida sintetik. Alasan yang mendasari antara lain insektisida sintetis lebih efektif dan biaya produksinya lebih rendah dibandingkan dengan insektisida alami. Faktor yang lain yaitu insektisida sintetis mudah didapat, praktis aplikasiannya, tidak perlu membuat sediaan sendiri, tersedia dalam jumlah banyak dan tidak perlu membudidayakan sendiri tanaman penghasil insektisida (Kardinan 2002).

Penggunaan insektisida sintesis dapat menimbulkan beberapa efek yaitu resistensi terhadap serangga, resurjensi serangga sasaran, pencemaran lingkungan, residu insektisida 
dan dapat menekan perkembangan musuh alami hama (Metcalf 1982). Salah satu upaya mengatasi masalah tersebut adalah mencari pengendalian alternatif yang dapat mengendalikan hama secara efektif dan ramah lingkungan yaitu menggunakan insektisida nabati.

Tanaman yang diduga dapat menjadi insektisida nabati adalah kemangi. Selama ini, kemangi hanya dikenal sebagai sayur yang digunakan sebagai lalapan segar dan obat tradisional. Ada satu tanaman yang mirip kemangi yaitu selasih yang terbukti mampu sebagai insektisida nabati yaitu repelen nyamuk (Musbiyana 2004).

\section{BAHAN DAN METODE}

\section{Waktu dan Tempat}

Penelitian dilaksanakan sejak Maret hingga Mei 2007 di bagian Parasitologi dan Entomologi Kesehatan, Departemen Ilmu Penyakit Hewan dan Kesehatan Masyarakat Veteriner, Fakultas Kedokteran Hewan, Institut Pertanian Bogor. Penyulingan dilakukan di Laboratorium Balai Penelitian Tanaman Obat dan Aromatik (BALITTRO), Cimanggu Bogor.

\section{Bahan dan Alat}

Bahan yang digunakan dalam penelitian ini antara lain: minyak kemangi, sekam, pakan ayam, susu bubuk, gula pasir, air, pengemulsi dan hewan uji berupa larva lalat rumah instar III awal.

Alat yang digunakan adalah kandang (kurungan) lalat, mangkok plastik, gelas plastik, kapas, nampan, pinset, pipet, kain kasa sebagai penutup gelas, timbangan, gelas ukur dan sendok plastik.

\section{Pemeliharaan Masal Larva Lalat Rumah (Rearing)}

Lalat dewasa diperoleh dari koloni yang telah dipelihara dan beradaptasi di Insektori Bagian Parasitologi dan Entomologi Kesehatan, Departemen Ilmu Penyakit Hewan dan Kesmavet FKH, IPB. Lalat dewasa dikembangbiakkan di kandang lalat. Di dalam kandang diletakkan mangkok plastik berisi media biakan dengan perbandingan antara pakan ayam dan sekam 3 : 1 kemudian diberi air secukupnya hingga terlihat cukup lembab kemudian diaduk hingga merata.

Media ini berfungsi sebagai tempat peneluran bagi lalat betina. Di dalam kandang juga disediakan air gula $10 \%$ atau susu bubuk dalam gelas plastik sebagai sumber karbohidrat untuk lalat. Telur dalam media biakan, akan menetas menjadi larva. Larva dipindahkan ke dalam nampan yang berisi pelet ayam kering, yang berfungsi sebagai nutrisi tambahan bagi larva. Larva ditunggu kira-kira 45 hari hingga menjadi instar III. Hasil pemeliharaan diperoleh persediaan larva instar III awal untuk pengujian. 


\section{Penyulingan Kemangi}

Bagian kemangi yang digunakan untuk penyulingan adalah daun. Daun kemangi dilayukan kurang lebih selama 24 jam untuk mengurangi kadar airnya. Selanjutnya daun kemangi disuling untuk memperoleh minyaknya. Alat penyuling berupa kukusan yang berisi air yang dilengkapi dengan saluran tabung penyuling dengan bagian ujungnya berupa kran yang tertutup. Kukusan ini diletakkan di atas bunsen yang telah dinyalakan. Daun kemangi yang telah dilayukan dimasukkan dalam kukusan, kemudian kukusan ditutup rapat-rapat, agar uap daun kemangi keluar melalui saluran tabung penyuling dan nyala api bunsen tetap kecil.

Uap daun kemangi yang mengalami pendinginan akan berubah menjadi air dan minyak. Air akan selalu berada di bawah minyak karena berat jenis air lebih berat dari pada berat jenis minyak. Air yang berada di bawah minyak harus dibuang terlebih dahulu sehingga minyak dapat dikeluarkan. Setelah air dikeluarkan dengan tuntas maka minyak yang keluar segera ditampung dalam wadah dan minyak siap digunakan untuk pengujian. Konsentrasi minyak kemangi dianggap 100\% (Sudaryani 1990).

\section{Pengujian}

Pengujian dilakukan dengan metode rancangan acak lengkap. Menggunakan 20 buah gelas yang berisi media biakan seberat 10 gram. Media diperoleh dari campuran pakan ayam dan sekam yang telah diaduk rata kemudian ditimbang sebanyak $10 \mathrm{~g}$. Penelitian ini terdiri atas 5 perlakuan, yaitu pemberian minyak kemangi dengan konsentrasi 0, 2,5, 5, 10, $20 \%$. Masing-masing perlakuan dilakukan pengulangan sebanyak empat kali (Priyono 1988).

Konsentrasi perlakuan diperoleh dengan mencampurkan minyak kemangi yang dianggap $100 \%$ dengan pengencer berupa aquades. Di setiap gelas plastik ditetesi pengemulsi sebanyak 0,1 ml. Menurut Priyono (1988), pencampuran ini menggunakan rumus :

$\mathrm{C}_{1} \cdot \mathrm{V}_{1}=\mathrm{C}_{2} \cdot \mathrm{V}_{2}$

Keterangan :

$\mathrm{C} 1=$ Konsentrasi ekstrak awal

$\mathrm{C} 2=$ Konsentrasi yang diinginkan

V1 = Volume yang dicari

V2 = Volume yang diinginkan

Setelah media untuk pengujian siap dilaksanakan di dalam setiap gelas plastik ditambahkan campuran kemangi dengan aquades sebanyak 6 $\mathrm{ml}$ kemudian diletakkan 25 ekor larva. Larva diamati tiap 24 jam untuk memantau pertumbuhannya sampai menjadi lalat dewasa.

\section{Pengamatan}

Pengamatan dilakukan dengan cara menghitung jumlah larva yang mati (mortalitas larva), jumlah pupa yang terbentuk setelah 4 hari dan jumlah pupa yang mengalami eklosi menjadi 
lalat Musca domestica setelah 3 hari dari masa pupa.

\section{Analisa Data}

Data hasil penelitian dianalisis menggunakan sidik ragam (ANOVA) dan dilanjutkan dengan uji wilayah berganda Duncan untuk menguji perbedaan diantara perlakuan yang ada.

\section{HASIL DAN PEMBAHASAN}

Hasil pengamatan pengaruh kemangi (Ocimum basilicum forma citratum) terhadap lalat rumah (Musca domestica) disajikan dalam bentuk gambar sebagai berikut :

Gambar 1 menunjukkan rata-rata jumlah kematian larva Musca domestica setelah berkontak dengan ekstrak kemangi. Secara statistik, konsentrasi kemangi 10 dan 2,5\% tidak berbeda nyata dengan kontrol. Hal ini berarti kemampuan larvasida minyak kemangi dengan konsentrasi 2,5 dan $10 \%$ tidak terlalu baik karena mortalitas yang ditimbulkan tidak berbeda dengan kontrol. Konsentrasi kemangi $5 \%$ jika dibandingkan konsentrasi 2,5 dan $10 \%$ dapat dikatakan memiliki kemampuan larvasida yang lebih baik karena secara statistik mortalitas pada konsentrasi $5 \%$ berbeda nyata dengan kontrol. Meskipun demikian, konsentrasi 5\% tidak berbeda nyata dengan konsentrasi 10\%. Data tersebut menunjukkan bahwa kematian larva yang ditimbulkan oleh kedua konsentrasi tidak berbeda. Kematian larva pada konsentrasi $10 \%$ lebih kecil dibandingkan konsentrasi $5 \%$.

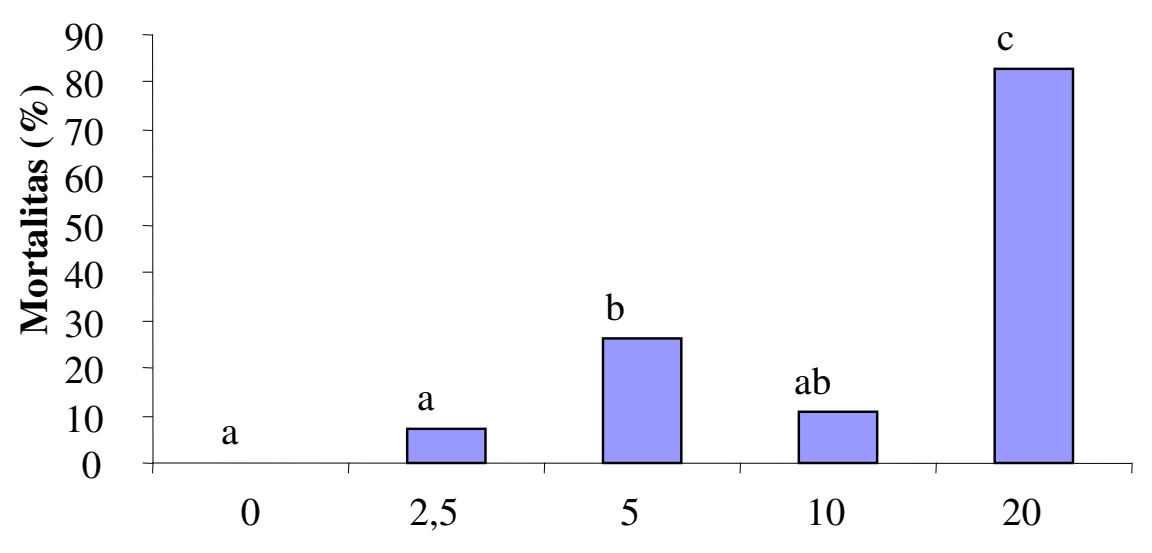

Konsentrasi minyak atsitri kemangi (\%)

Gambar 1. Rata-rata kematian larva Musca domestica setelah berkontak dengan extrak kemangi 
Konsentrasi kemangi $20 \%$ berbeda nyata dengan ketiga konsentrasi lainnya dan juga kontrol. Konsentrasi kemangi 20\% menyebabkan kematian sebanyak $83 \%$. Hal ini membuktikan bahwa konsentrasi $20 \%$ memiliki kemampuan larvasida terbaik dibanding konsentrasi yang lain.

Senyawa bioaktif (senyawa yang bertanggung jawab dalam menghasilkan efek) yang diduga berfungsi sebagai larvasida dari kemangi adalah eugenol dan methyl clavical. Senyawa bioaktif ini merupakan senyawa penyusun minyak atsiri yang terkandung dalam tanaman kemangi.

Hasil yang diperoleh setelah 4 hari pemaparan minyak kemangi terhadap larva memperlihatkan bahwa tubuh larva seperti terbakar. Warna tubuh larva menjadi coklat kehitaman, kaku dan kering (Gambar 2). Minyak kemangi berfungsi sebagai larvasida dengan cara kerja sebagai racun kontak (contact poison) melalui permukaan tubuh larva karena fenol (eugenol) mudah terserap melalui kulit (Wilbraham \& Matta 1992). Menurut Prasojo (1984), racun kontak akan meresap ke dalam tubuh binatang lewat kulit luar dan binatang akan mati bila tersentuh kulit luarnya. Racun kontak akan masuk dalam tubuh larva melalui kutikula sehingga apabila insektisida kontak langsung pada kulit maka sedikit demi sedikit molekul insektisida akan masuk ke dalam tubuh larva. Seiring dengan bertambahnya waktu maka akumulasi dari insektisida yang masuk ke tubuh larva dapat menyebabkan kematian (Wudianto 1998). Fenol dapat menyebabkan cacat bakar dan amat beracun (Wilbraham \& Matta 1992). Eugenol menyebabkan alergi jika terpapar pada kulit. Eugenol dosis tinggi bahkan dapat mengakibatkan efek seperti terbakar (Anonim 2006). Hal ini yang mengakibatkan kematian larva dan bentuk fisik larva terlihat seperti terbakar. Eugenol juga bekerja pada sistem syaraf. Eugenol merupakan senyawa fenol yang memiliki gugus alkohol sehingga dapat melemahkan dan mengganggu sistem syaraf (Hart 1990). Diduga zat ini mempengaruhi sistem syaraf larva walaupun tidak dilakukan penelitian lebih lanjut mengenai hal tersebut.

Gambar 3 menunjukkan rata-rata pupa Musca domestica yang tebentuk (ekdisis) setelah berkontak dengan ekstrak kemangi. Waktu pengamatan untuk menghitung jumlah pupa yaitu 4 hari. Secara statistik konsentrasi kemangi 2,5 dan $10 \%$ tidak berbeda nyata dengan kontrol. Jumlah larva yang mengalami ekdisis (perubahan larva menjadi pupa) pada konsentrasi kemangi 2,5 dan 10\% tidak berbeda dengan kontrol. 


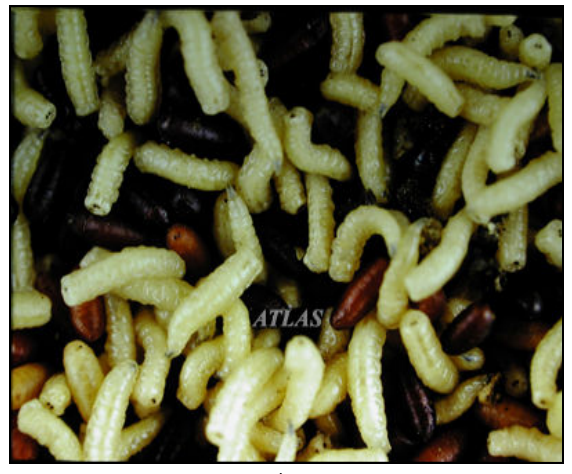

A.

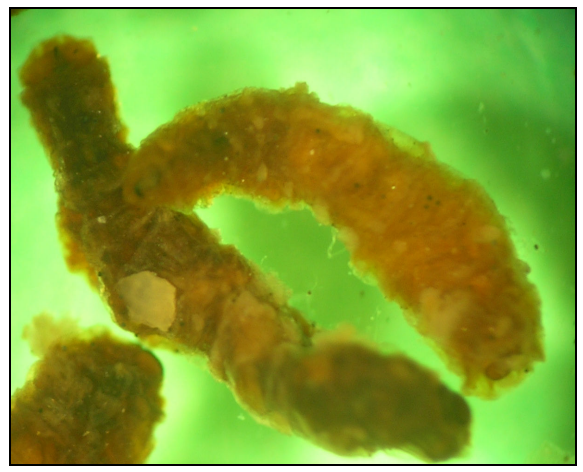

B.

Gambar 2. Larva Musca domestica A. Normal (Rutz \& Kaufman 2006)

B. Mati setelah terpapar minyak kemangi

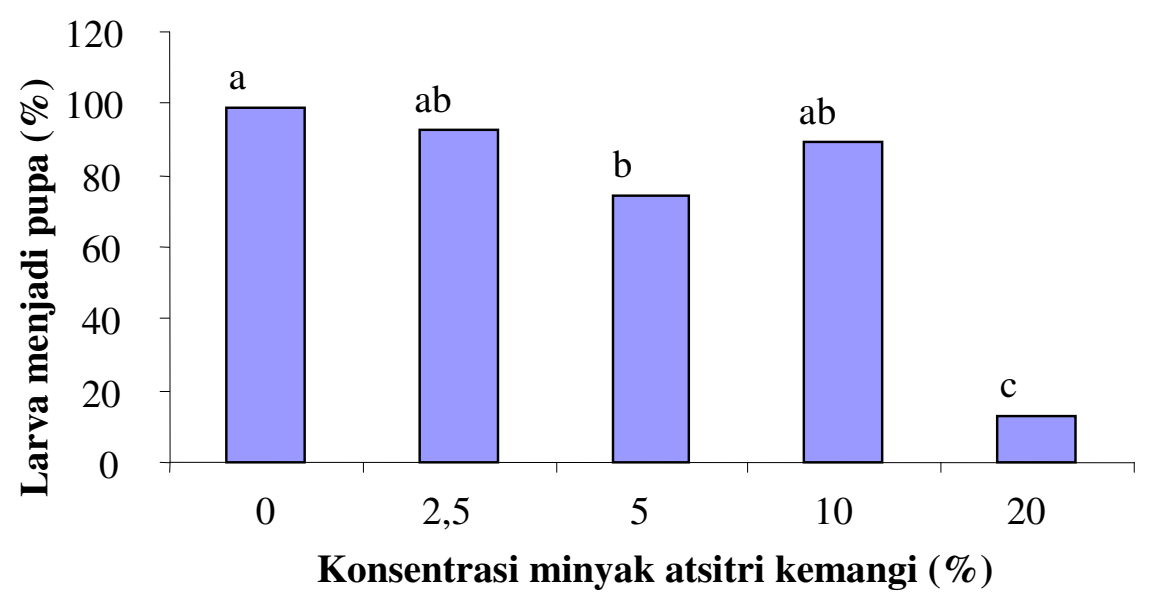

Gambar 3. Rata-rata kemampuan ekdisis lalat Musca domestica setelah berkontak dengan ekstrak kemangi

Konsentrasi kemangi 2,5 dan 10\% juga tidak berbeda nyata dengan konsentrasi $5 \%$ tetapi konsentrasi kemangi $5 \%$ berbeda nyata dengan kontrol. Hal ini berarti jumlah larva yang ekdisis pada konsentrasi 2,5 dan $10 \%$ tidak berbeda dengan kontrol dan mendekati jumlah larva yang ekdisis pada konsentrasi $5 \%$.

Konsentrasi $20 \%$ berbeda nyata dengan ketiga konsentrasi yang lain juga kontrol. Kemampuan ekdisis larva pada konsentrasi $20 \%$ sangat rendah dibanding ketiga konsentrasi yang lain dan kontrol. Jumlah pupa yang terbentuk berbanding terbalik dengan jumlah kematian larva, semakin banyak larva yang mati maka jumlah pupa semakin sedikit.

Zat bioaktif dalam minyak kemangi yang dapat berfungsi sebagai larvasida selain eugenol adalah methyl 
clavical. Zat ini termasuk kelompok ether (Lowry 2007). Menurut Wilbraham \& Matta (1992), methyl clavical juga memiliki efek anastetikum. Seperti halnya contoh kelompok ether yang lain, diduga methyl clavical bekerja mengganggu kerja susunan syaraf larva. Semakin tinggi ekstrak kemangi yang digunakan maka semakin tinggi zat bioaktif di dalam kemangi yang bekerja mempengaruhi proses ekdisis larva Musca domestica. Hasil penelitian pada konsentrasi kemangi 20\% menunjukan kemampuan ekdisis larva sangat rendah (hanya 13\%) dibanding konsentrasi kemangi yang lain.

Gambar 4 menunjukkan jumlah eklosi (perubahan pupa menjadi lalat) lalat Musca domestica setelah berkontak dengan minyak kemangi. Penghitungan jumlah lalat dilakukan setelah pupa mengalami eklosi. Secara statistik konsentrasi kemangi 2,5, 5 dan $10 \%$ saling tidak berbeda nyata. Ketiga konsentrasi ini juga tidak berbeda nyata terhadap kontrol.

Konsentrasi kemangi 20\% berbeda nyata dengan konsentrasi yang lain dan kontrol. Kemampuan eklosi lalat rumah pada konsentrasi 20\% sangat rendah. Kemampuan eklosi berbanding lurus terhadap kemampuan ekdisis. Semakin sedikit pupa yang terbentuk maka lalat yang muncul juga semakin sedikit dan sebaliknya.

Senyawa lain yang terkandung dalam kemangi dan diduga memiliki pengaruh terhadap mortalitas larva adalah saponin. Saponin dalam lerak dapat merusak dinding traktus digestivus (Aminah 1995). Penelitian mengenai saponin dalam kemangi belum diketahui secara pasti tetapi jika dianalogikan, diduga saponin dalam kemangi juga dapat menyebabkan kematian larva dengan cara yang sama dengan lerak. Saponin merupakan surfaktan kuat, konsentrasi rendah dapat bersifat toksik pada mamalia karena menyebabkan hemolisis sel darah merah (Vickery \& Vickery 1981).

\section{KESIMPULAN}

1. Kematian larva terbanyak, kemampuan ekdisis lalat terendah, kemampuan eklosi lalat terendah Musca domestica dihasilkan pada konsentrasi ekstrak kemangi 20\%.

2. Ekstrak kemangi sebagai larvasida lalat Musca domestica terbaik pada konsentrasi $20 \%$. 


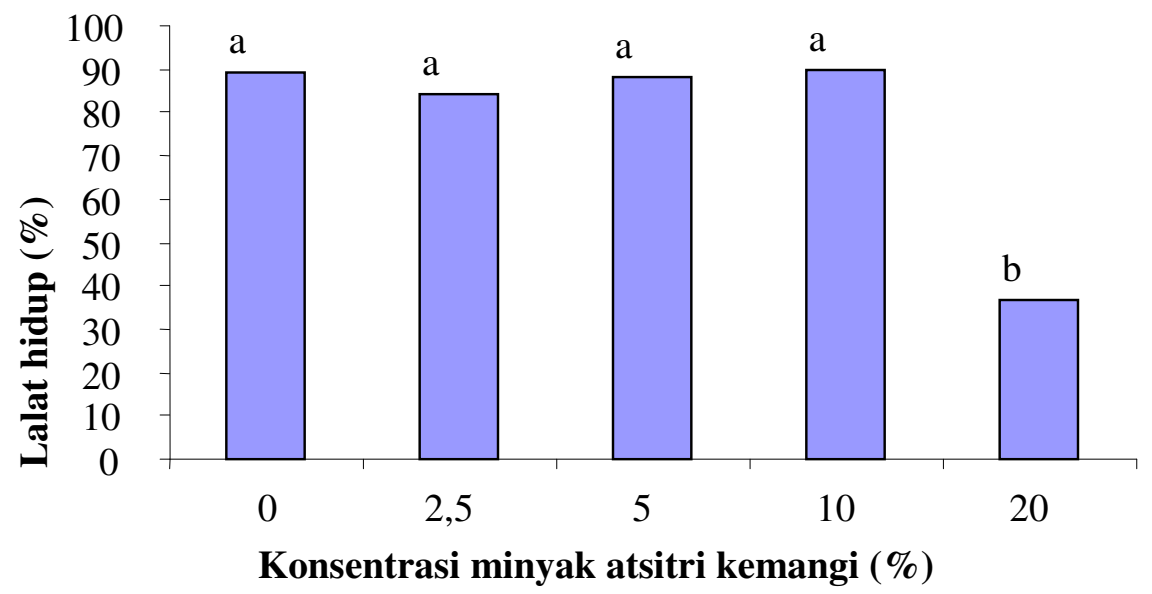

Gambar 4. Rata-rata kemampuan eklosi lalat Musca domestica setelah berkontak dengan ekstrak kemangi

\section{SARAN}

Perlu dilakukan penelitian lanjutan mengenai pengaruh ekstrak kemangi terhadap serangga lain. Uji konsentrasi dan ekonomis untuk transformasi produksi perlu dilakukan.

\section{DAFTAR PUSTAKA}

Anonim. 2006. Clove (Eugenia aromatica dan Clove Oil (Eugenol).

http://www.medlineplusherbsan dsuplement.com [28 Juli 2007].

Aminah NS. 1995. Evaluasi Tiga Jenis Tumbuhan Sebagai Insektisida dan Repelan Terhadap Nyamuk di Laboratorium [Tesis]. Bogor: Program Pasca Sarjana. Institut Pertanian Bogor.

Hart H. 1990. Kimia Organik. Suminar, penerjemah; Jakarta: Penerbit Erlangga. Terjemahan dari: Organic Chemistry.
Kardinan A. 2002. Pestisida Nabati Ramuan dan Aplikasi. Jakarta: Penebar Swadaya. Jakarta.

Lowry R. 2007. Antimicrobia Packaging. http://www.profitthroughinnovat ion.com [28 Juli 2007].

Metcalf RL. 1982. Insecticide in Pest management Introduction to Insect Pest Management. New York: John Willen and Sons.

Musbiyana S. 2004. Pengaruh Daun Selasih Sebagai Repelan Terhadap Nyamuk Aedes aegypti [Skripsi]. Bogor: FKH IPB.

Prasodjo BJ. 1984. Petunjuk Penggunaan Pestisida. Jakarta: Penebar Swadaya.

Prijono D, Triwidodo H. 1993. Pemanfaatan Insektisida Nabati di Tingkat Petani dalam Proceding Seminar Hasil Penelitian dalam Rangka Pemanfaatan Pestisida Nabati. 
Balittro. Bogor 1-2 Desember 1993. Bogor.

Priyono D. 1988. Pengujian Insektisida : Penuntun Praktikum. Fakultas Pertanian IPB. Bogor.

Rutz DA, Kaufman PE. 2006. House Fly Larvae. http//www.entomology.cornell.e du//maggot 1600.jpg [18 September 2007].

Sudaryani T. 1990. Budidaya dan Penyulingan Nilam. Swadaya. Jakarta.
Vickery ML, Vickery B. 1981. Secondary Plant Metabolism. Hongkong: The Macmillan Press LTD.

Wilbraham AC, Matta MS. 1992. Pengantar Kimia Organik dan Hayati. Suminar A, (penerjemah). Terjemahan dari : Introduction to Organic and Biological Chemistry. Bandung: Penerbit ITB.

Wudianto R. 1998. Petunjuk Penggunaan Pestisida. Jakarta: Penebar Swadaya. 